\title{
KAJIAN HUKUM ISLAM TERHADAP UJARAN KEBENCIAN/HATE SPEECH DAN BATASAN KEBEBASAN BEREKSPRESI
}

\author{
Yayan Muhammad Royani \\ UIN Walisongo Semarang \\ yayanmroyani@gmail.com
}

\begin{abstract}
Hate speech is a special term for criminal offenses such as hate expression, incitement, libel and defamation on behalf of race, ethnicity, religion, class or gender. That action is flare in public communication, especially in the Internet media. Although there have been various regulations governing, countermeasures against hate speech is not maximized. It could not be separated from the difficulty of determining the boundaries of hate speech with freedom of expression. This study aims to answer these problems in the perspective of Islamic law. The theory used is takzir and Maqasidu al-Syari'ah. The results of this study illustrate that the hate speech is a criminal offense punishable takzir and require a social approach in overcoming it. In the formulation of Islamic law, definition of hate speech is taken from the Korans argument that protect human rights in order to be limiting freedom of expression.
\end{abstract}

Keywords: Speech, Hate, Law, Islam

\section{A. Pendahuluan}

Hate speech/ujaran kebencian merupakan istilah untuk perbuatan berupa ungkapan dalam pidato, ceramah, orasi, tulisan, gambar maupun sosial media yang mengandung unsur pencemaran nama baik, penistaan, perbuatan tidak menyenangkan, memprovokasi, menghasut atau penyebaran berita bohong. Perbuatan tersebut berdampak pada tindakan diskriminasi, kekerasan, penghilangan nyawa bahkan konflik sosial. Bertujuan untuk menghasut dan menyulut kebencian terhadap individu dan kelompok masyarakat dalam berbagai komunitas. ${ }^{1}$

Hate speech telah menjadi permasalahan hukum dan sosial saat ini. Di era globalisasi yang didukung media informasi tanpa batas, banyak pihak atas dasar kebebasan berekspresi melanggar hak asasi orang lain. Yaitu megeluarkan ujaran atau ungkapan yang tidak didasarkan pada bukti yang dapat dipertanggungjawabkan. Kasus-kasus seperti pencemaran nama baik dan hasutan kebencian masih menghiasi pemberitaan di media massa.

\footnotetext{
${ }^{1}$ Peraturan Kapolri nomor SE/06/X/2015
} 
Selain dapat berdampak pada tindakan diskriminasi dan kekerasan, yang lebih berbahaya adalah timbulnya disintegrasi dan disharmonis sosial. Sebagai negara yang berdiri di atas kemajemukan, pemerintah perlu memperhatikan faktor-foktor yang tidak sejalan dengan nilai-nilai Pancasila, konstitusi dan demokrasi. Tindakan hate speech atas dasar kebencian terhadap ras, suku dan agama dapat menjadi faktor utama perpecahan bangsa. Oleh karenanya, perlu penegakan hukum secara tegas atas tindakan yang mengandung unsur hate speech/ujaran kebencian.

Di Indonesia, hate speech telah di atur dalam berbagai regulasi maupun ratifikasi kovenan internasional. Akan tetapi tidak berdampak signifikan terhadap penanggulangan hate speech di masyarakat. Sebagai contoh masih maraknya kasus penghinaan dan pencemaran nama baik kepada simbol negara maupun individu. Berkaitan dengan keyakinan, maka masih ditemukan kasus penodaan agama lewat sebuah karya, pidato politik atau status di media sosial. Lainnya kasus saling menghina, mensesatkan bahkan menghasut untuk melakukan tindakan anarkis antar kelompok sosial masyarakat. Tindakan-tindakan tersebut pada realitanya belum mendapatkan ketegasan hukum.

Sebagai agama terbesar di Indonesia, Islam perlu memberikan subangsih dalam menanggulangi hate speech, yaitu sebagai upaya merajut harmonis, persatuan dan kesatuan bangsa. Selain dengan pendekatan sosial, pendekatan normatif juga perlu diupayakan. Fiqih sebagai bagian dari produk hukum Islam diharapkan dapat ikut menjawab permasalahan nasional. atas pertimbangan tersebut, penulis mengambil tema penelitian ini dengan judul "Kajian Hukum Islam terhadap Hate Speech dan Batasan Kebebasan Berekspresi”"

Penelitian ini bertujuan untuk menjawab persoalan secara teoritis tentang pandangan Hukum Islam terhadap ujaran kebencian dan kebebasan berekspresi. Selama ini belum ada kajian yang membahas problem filosofis antara kebebasan berekspresi dan pembatasannya pada ujaran kebencian dalam perspektif Hukum Islam. Akibatnya belum ada sumbangan akademis secara komprehensif yang dapat menjadi pertimbangan dalam menjawab persoalan maraknya ujaran kebencian di masyarakat.

Adapun sumbangan terhadap persoalan sosial maka tidak dapat dilepaskan dari fenomena kekinian. Dengan perkembangan media sosial di dunia maya, didorong merosotnya nilai-nilai moralitas dan toleransi, mengakibatkan maraknya ujaran kebencian. Dalam menanggulangi tindak pidana ujaran kebencian tersebut, regulasi yang ada dianggap tidak cukup efektif. Perlu adanya kebijakan kriminal dari aspek non penal berupa sumbangan akademis dari sudut pandang Hukum Islam untuk menumbuhkan kesadaran akan bahaya tindakan tersebut.

Penelitian ini menggunakan pendekatan teori yang terdapat dalam hukum pidana Islam. Dalam meneliti ujaran kebencian, maka secara spesifik teori yang digunakan adalah jarimah ta'zir. Jarimah ta'zir menurut 'Audah 
adalah jarimah yang diancam hukuman takzir, dalam ketentuan syariah belum ditentukan kadar hukumannya. ${ }^{2}$

Selain pendekatan fiqih, sebagai dasar metodologi memformulasikan hukum Islam, peneliti menggunakan teori-teori yang terdapat dalam kajian ushul fiqh. Untuk menjawab permasalahan hate speech, maka menggunakan teori Maqasidu al-Syari'ah Menurut Wahbah Zuhaili Maqasidu al-Syari'ah adalah makna-makna dan tujuan yang diperhatikan oleh syariah di semua hukumnya atau tujuan dari syariah itu sendiri. ${ }^{3}$ Pada peneltian hate speech, teori Maqasidu al-Syari'ah tidak sebatas dijadikan pelengkap dari pembahasan ushulu al-fiqhi tentang maslahat, lebih dari itu dijadikan metode istinbath hukum itu sendiri.

\section{B. Definisi Ujaran Kebencian/ Hates Speech}

Hate speech atau ujaran kebencian merupakan definisi untuk tindak kejahatan yang berkaitan dengan perkataan bermuatan umpatan, penghinaan terhadap individu atau kelompok atas dasar ras, sex, orientasi seksual, etnis dan agama. Dimana perbuatan tersebut merupakan bentuk penghinaan yang menimbulkan suasana permusuhan, intimidasi serta merupakan bagian dari tindakan pencemaran. ${ }^{4}$ Dalam Oxford Dictionary hate speech diartikan sebagai perkataan yang mengekspresikan kebencian dan intoleransi terhadap kelompok sosial, biasanya berbasis ras dan seksualitas.

Willian B. Fisch memberikan definisi sebagai hasutan kebencian terhadap kelompok atau individu atas dasar ras, sex dan orientasi seksual, etnis, agama. Menurutnya sangat erat dengan pemaknaan dalam International Covenant on Civil and Political Rigth pada tahun 1966 artikel Nomor 20 ayat 2 tentang larangan negara untuk melakukan advokasi atas kebencian atas ras dan agama yang merupakan hasutan untuk diskriminasi, dan menimbulkan permusuhan serta kekerasan. ${ }^{5}$

Menurut Katharine Gelber hate speech merujuk kepada sejarah hak asasi manusia, yaitu merupakan perkataan yang mengandung unsur bahaya dan melanggar hak dasar orang lain. Perkataan tersebut berkontribusi terhadap miliu kebencian, kekerasan, marjinaliasi dan pelemahan berbagai sektor pada suatu komunitas. ${ }^{6}$ Pada dasarnya kekerasan tersebut telah melukai harkat martabat manusia.

Menurut Brian M. Britt, hate speech bisa diartikan sebagai kata yang melukai. Problemnya adalah apakah sebuah kata memilik kekuatan untuk

${ }^{2}$ Audah, 'Abdul Qadir. 2011. al-Tasyri' al-Jinai al-Islami. Jilid I. Bairut-Libanon: Darul Kutub al-Islamiyyah. Hlm. 64.

${ }^{3}$ Zuhaili, Wahbah. 2005. Ushulu al-Fiqhi. Jilid II. Damaskus: Darulfikr. Hlm. 307.

${ }^{4}$ Brison, Susan J. The Autonomy Defense of Free Speech. Chicago Journals. The University of Chicago. Volume 108 Nomor 2, 1998. Hlm. 313. http:/ /www.jstor.org/ stable/ 10.1086/ 233807 diakses 11-05-2016 14:57

5 Fisch, Willian B. Hate Speech in the Constitutional Law of the United States. The American Journal of Comparative Law volume. 50. American Society of Comparative Law. 2002. Hlm. 463. http://www.jstor.org/stable/840886 diakses pada 11-05-2016 14:50

${ }_{6}$ Gelber, Katharine. 2002. Speaking Back, Free Speak versus Hate Speech Debat. Amsterdam: John Benjamins Publishing Company. Hlm. 26. 
melakukan hal tersebut? Di Amerika, perkataan berupa hinaan dan umpatan masih dilegalkan selama tidak menghasut untuk melaksanakan tindak kriminal atau permusuhan. Terdapat pandangan bahwa hanya perkataan yang dapat melukai yang merupakan tindak pidana tersendiri, atau merupakan bagian dari serangan terhadap psikis yang subjektif.

Hate speech sesungguhnya tidak hanya ungkapan yang deskriptif, akan tetapi telah menjadi istilah penghinaan yang membiaskan batasan antara ungkapan/seruan dan penggunaan kuasa kata. Apabila yang dimaksud adalah dengan penggunaan kuasa kata, maka hal tersebut bisa dijadikan alasan untuk pemidaan dan sebaliknya. Selanjutnya hate speech biasa dikaitkan dengan kebencian atas dasar ras, sex, etnis maupun agama dengan menggunakan perkataan yang berbahaya.

Menurut Alexander Brown istilah hate speech tidak hanya digunakan untuk ungkapan dalam bentuk kata, tulisan atau verbal, tetapi mencakup seluruh kehendak ekspresi seseorang. Mencakup simbol, gambar, gestur, musik, gambar bergerak atau perbuatan lain yang biasa digunakan untuk mengekpresikan kehendak yang mempunyai arti. Menurutnya bisa saja menggunaan kata ekspresi sebagai definisi, akan tetapi kata tersebut tidak digunakan sebagai pembatas kebebasan berekpresi dalam regulasi. Sehingga kata hate speech secara kualitas harus diartikan sebagai ujaran plus, kehendak ilegal atau ujaran dengan kehendak yang mempunyai efek emosional. ${ }^{7}$

Regulasi tentang hate speech diterima oleh seluruh kalangan di Barat. Selain merujuk kepada sejarah hak asasi manusia khususnya respon terhadap kasus Nazi, juga menjadi batasan bagi konsep free speech dan kebebasan berekspresi. Pada saat itu majlis umum PBB berdasarkan dekalarasi hak asasi manusia mulai menjalankan era baru perlindungan HAM yang modern. ${ }^{8}$

Dalam Buku Saku Penanganan Ujaran Kebencian (hate speech) yang dikeluarkan oleh Komisi Nasional Hak Asasi Manusia, terdapat contoh sejarah ujaran kebencian yang berujung genosida. Yaitu kasus pemusnahan Suku Tutsi di Rwanda. Dalam waktu 1 minggu, 800,000 atau paling banyak sekitar satu jiwa etnis Tutsi menjadi korban pembantaian berbasis kebencian. Jumlah ini adalah $1 / 3$ dari seluruh populasi Tutsi. Perempuan Tutsi menjadi target perkosaan secara sistematis.

Tragedi ini dimulai dari hal sederhana. Pada tahun 1994, populasi Rwanda berjumlah 7 juta terdiri dari 3 kelompok etnis yaitu Hutu (85\%), Tutsi (14\%) and Twa (1\%). Di awal 1990, kelompok ekstrimis Hutu di dalam elit politik menyalahkan seluruh etnis Tutsi sebagai penyebab meningkatnya tekanan sosial, ekonomi dan politik. Etnis Tutsi juga dituduh mendukung kelompok dominan dalam pemberontak Tutsi, yaitu Rwandan Patriotic Front (RPF). Penghasut juga memanfaatkan ingatan masyarakat etnis Hutu tentang pemerintahan penindas yang berasal dari etnis Tutsi. Akibatnya banyak dari

\footnotetext{
${ }^{7}$ Alexader, Brown. 2015. Hate Speech Law, a Philosopical Examination. New York: Routledge, hlm. 5

${ }^{8}$ Britt, Brian M. Curses. Left and Right: Hate Speech and Biblical Tradition. Journal of the American Academy of Religion. Volume 78, Nomor 3. Oxford University Press. 2010. Hlm. 632-638. http://www.jstor.org/stable/27919231 diakses pada 11-05-2016 14:40
} 
etnis Hutu takut dengan kembalinya minoritas yaitu suku Tutsi. Kelompok penghasut melakukan Propaganda melalui radio, selebaran yang terus menerus serta bentuk lainnya yang akhirnya berujung pada genosida.

Berdasarkan pengalaman di Rwanda, hate speech menjadi sumber utama konflik horizontal maupun pertikal dalam masyarakat. Konflik tersebut biasanya sampai kepada tindakan intoleransi yang melanggar hukum. Istilah yang dipakai untuk perbuatan tersebut adalah hate crime. Berbeda dengan hate speech yang menjadi pembatas atas kebebasan bereskpresi, hate crime merupakan tindakan pidana langsung terhadap suatu golongan atas nama ras, agama, suku, kebangsaan ataupun orintasi seksual.

Menurut Maruli CC. Simanjuntak istilah kejahatan berbasis kebencian (hate crime) masih cukup asing dan belum dikenal di Indonesia. Secara sedarhana bisa diartikan sebagai peristiwa kejahatan yang dilandasi dan kerana bermotif kebencian kolektif. Istilah ini dipopulerkan oleh tiga anggota parlemen Amerika Serikat: John Conyer, Barbara Connelly dan Mario Biaggi. ${ }^{9}$

Menurut Gerstenfeld mengartikan hate crime sebagai tindak pidana yang dilakukan setidak-tidaknya, atau sebagian, dengan motivasi adanya kelompok afiliasi korban berdasarkan kelompok ras, agama, etnis, gender, ketidakmampuan dan lain-lain. ${ }^{10}$ Mustofa memperkuat definisi tersebut dengan memberi contoh peristiwa di Indonesia. Diantaranya adalah penyerangan terhadap etnis China, pengikut Ahmadiyah, perlakuan tidak adil terhadap orang yang dituduh mempunyai hubungan dengan PKI dan organisasi yang bernaung dibawahnya.

Selain berbeda dengan hate crime, hate speech juga berbeda dengan tindak pidana penghinaan secara umum. Dalam KUHP penghinaan di atur dalam BAB XVI yang dibagi ke dalam tujuh kelompok, yaitu menista, fitnah, penghinaan ringan, penghinaan terhadap pegawai negeri, pengaduan fitnah, persangkaan palsu dan penistaan terhadap orang yang telah mati. Adapun bentuk-bentuk penghinaan secara khusus, yaitu penghinaan terhadap presiden, penghinaan terhadap lembaga umum dan penghinaan terhadap golongan, ras, dan agama.

Hate speech tergolong pada penghinaan dalam bentuk khusus karena objek penghinaan adalah suatu hal tertentu. Berbeda dengan pasal penghinaan secara umum yang berlaku bagi setiap orang, hate speech mengkhususkan pada bentuk golongan berupa suku, ras, kebangsaan maupun agama. Dalam hal ini membawa konsekuensi bentuk delik, dimana pasal penghinaan secara umum merupakan delik aduan, adapun penghinaan dalam bentuk khusus adalah delik biasa.

Dalam teori hukum pidana, untuk menentukan suatu perbuatan menjadi tindak pidana adalah dengan mengkriminalisasi perbuatan tersebut. Menurut Barda Nawawi Arief, kebijakan kriminalisasi merupakan suatu kebijakan

${ }^{9}$ Simanjuntak, CC Maruli. Tanpa Tahun. Atas Nama Kebencian, Kajian Kasus-Kasus Kejahatan Berbasis Kebencian di Indonesia. Jakarta: Yayasan Bantuan Hukum Indonesia. Hlm. 3.

${ }^{10}$ Gerstenfeld, Phyllis B. 2004. Hate Crime: Causes, Control and Controversies. London UK: Sage Publications. Hlm. 9 
dalam menetapkan suatu perbuatan yang semula bukan tindak pidana menjadi suatu tindak pidana. Pada hakikatnya, kebijakan kriminalisasi merupakan bagian dari kebijakan kriminal (criminal policy) dengan menggunakan sarana hukum pidana (penal), dan oleh karena itu termasuk bagian dari kebijakan hukum pidana (penal policy). ${ }^{11}$

Diperlukan kebijakan definitif tentang hate speech yang dapat menjamin kepastian hukum. Dengan tersebarnya tindak pidana hate speech di berbagai pasal dalam berbagai regulasi, sangat memungkinkan menimbulkan problem yuridis.

\section{Hate Speech dan Kebebasan Berekspresi}

Problem hate speech berkaitan langsung dengan kebebasan berekspresi, yang secara spesifik merujuk kepada free speech/kebebasan berbicara. Bahwa kebebasan berekspresi merupakan hak asasi yang didasari pada prinsipprinsip umum. Secara mendasar manusia diberi kebebasan untuk mengekpresikan apapun atas dasar pikiran dan keyakinananya.

Menurut Anna Weber, pembatasan terhadap kebebasan berekspresi terdapat dalam European Convention of Human Right (ECHR) Pasal 10 ayat (2). Dalam artikel nomor 10 dejelaskan bahwa dalam melaksanakan hak kebebasan berekspresi maka harus memperhatikan juga kewajiban dan tanggungjawab. Lain dari itu seseorang harus memperhatikan berbagai hal seperti formalitas, kondisi, pembatasan dan hukuman sebagaimana di atur dalam undang-undang. ${ }^{12}$

Merujuk kepada regulasi HAM didasarkan pada Kovenan Sipil dan Politik kebebasan tersebut dapat dibatasi. Yaitu adalah semata-mata untuk menjamin keamanan publik, kesehatan publik, moral publik dan hak asasi orang lain. Syarat lain dari pembatasan tersebut adalah harus terlegislasikan berupa produk undang-undang.

Legislasi hate speech adalah mencakup penanggulangan terhadap merebaknya tindakan tersebut, menurunkan peningkatan kebencian, penghinaan dan kekerasan terhadap kelompok tertentu. Menurut membela free speech maka legislasi pembatasan tidak diperlukan. Hate speech dapat efektif ditanggulangi dengan memegang teguh prinsip kenyamanan atas kebebasan berbicara sebisa mungkin. Bahkan secara historis, perkataan mempunyai tempat yang tinggi dari sudut pandang kebebasan manusisa, sehingga dapat menjamin perkembangannya sendiri tanpa aturan yang ketat.

Regulasi tentang hate speech datang langsung berhadapan dengan free speech. Sehingga perlu kebijakan yang tepat dan dapat diterima, mengingat masyarakat sudah mengetahui tentang dasar dari kebebasan berbicara. Perlu

\footnotetext{
${ }^{11}$ Nawawi Arief, Barda. 2010. Bunga Rampai Kebijakan Hukum Pidana (Perkembangan Penyusunan Konsep KUHP Baru), Jakarta: Kencana.

${ }^{12}$ Weber, Anna. 1999. Hand Book of Hate Speech. France: Council of Europe Publishing. Hlm. 30
} 
adanya keseimbangan antara menjaga hak kebebasan berbicara dengan hak orang lain untuk tidak tersakiti karena gangguan dan intimidasi. ${ }^{13}$

Problem kebebasan berkepresi dengan menetapkan ujaran kebencian sebagai pembatas, pada prakteknya sangat rumit. Di Amerika, kebebasan berekspresi dianggap telah mendiskriminasi dan mensubordinasi kelompok minoritas. Sebagai contoh ungkapan "Apro-Amerika" untuk etnis AfrikaAmerika atau perkataan sexis bagi kaum perempuan yang dikritik oleh feminis. Ujaran kebencian telah masuk dalam berbagai aspek politik, ekonomi, sosial maupun budaya. ${ }^{14}$

Kritik terhadap kebebasan berkespresi juga dilakukan di daerah-daerah. Sebagai contoh Code Stanford yang berisi batasan kebebasan berekspresi dengan menentukan larangan sebagai berikut: 1) dengan indikasi menghina dan menstigma individual atas dasar ras, sex, warna kulit, agama, orientasi seksual maupun etnik. 2) ditujukan kepada individu maupun kelompok. 3) digunakan untuk menghina atau menyerang dengan kata-kata atau simbol yang dipahami sebagai penyampaian langsung atau kebencian yang mendalam atau penghinaan atas hak asasi manusia atas dasar ras, sex, warna kulit, agama, orientasi seksual maupun etnik. ${ }^{15}$

Menurut Nicholas Wolfson mengutif pendapat Plato dan Aristoteles, bahwa pada suatu masyarakat homogen dan tertutup mempunyai nilai dasar moral yang disepakati sehingga dapat membatasi ekspresi kebencian. Akan tetapi sebagaimana pendapat Spinoza bahwa manusia akan berfikir apa yang disenangi, dan berkata apa yang dipikirkan. Manusia hidup dalam masyarakat yang beragam, relativistik, keterbagian dan perdebatan, bisa atas dasar masalah seks, keluarga, nilai-nilai, dan tujuan dari kehidupan.

Kebebasan berekpresi di Amerika sangat berkaitan dengan konsep kebenaran. Menurut teori pragmatis, setiap kebenaran harus dapat diverifikasi dan dibuktikan secara faktual. Bisa didasarkan pada dialog, debat maupun konsensus. Kaitannya dengan keyakinan yang diekspresikan, maka dipastikan tidak ada landasan kebenaran, sehingga setiap orang hanya bisa menerima. Adapun berkaitan dengan fakta, selama ekspresi sesuai dengan kenyataan dikatakan sebagai kebenaran. ${ }^{16}$

\section{Hate Speech dalam Regulasi Nasional Dan Internasional}

Ketentuan soal larangan berujar kebencian sebenarnya telah diatur dalam sejumlah peraturan perundang-undangan. Misalnya saja dalam UU No. 1 Tahun 1946 tentang KUHP, UU No. 39 Tahun 1999 tentang HAM, UU No 40 Tahun 2008 tentang Penghapusan Diskriminasi Ras dan Etnis, UU No 11

${ }^{13}$ Gelber, Katharine. 2002. Speaking Back, Free Speak versus Hate Speech Debat. Amsterdam: John Benjamins Publishing Company. Hlm. 2-26.

${ }^{14}$ Nicholas, Wolfson. 1997. Hate Speech, Sex Speech, Free Speech. London: Greenwood Publishing Group. Hlm. 1-20.

${ }^{15}$ Joshua Cohen, "Freedom of Expression, dalam Philosophy \& Public Affairs Vol. 22, No. 3, Summer, 1993, Hlm. 207-263. Stable URL: http://www.jstor.org/stable/2265305. Accessed: 11-05-2016 15:09 UTC

${ }^{16}$ Nicholas, Wolfson. 1997. Hate Speech, Sex Speech, Free Speech. London: Greenwood Publishing Group. Hlm. 1-20. 
Tahun 2008 tentang Informasi dan Transaksi Elektronika, UU No 7 Tahun 2012 tentang Penanganan Konflik Sosial serta Peraturan Kapolri No 8 Tahun 2013 tentang Teknik Penanganan Konflik Sosial. Secara spesifik, pasal-pasal tersebut adalah sebagai berikut:

Pertama, terdapat dalam KUHP Pasal 156 yang berbunyi:

"Barangsiapa di muka umum menyatakan perasaan permusuhan, kebencian atau penghinaan terhadap suatu atau beberapa golongan rakyat Indonesia, diancam dengan pidana penjara paling lama empat tahun atau pidana denda paling banyak empat ribu lima ratus rupiah. Perkataan golongan dalam pasal ini dan pasal berikutnya berarti tiaptiap bagian dari rakyat Indonesia yang berbeda dengan suatu atau beberapa hagian lainnya karena ras, negeri asal, agama, tempat, asal, keturunan, kebangsaan atau kedudukan menurut hukum tata negara."

Menurut Andi Hamzah pasal ini tidaklah murni diambil dari WvS Belanda yang asli. Karena penduduk Belanda sangatlah homogen. Sehingga pasal ini sengaja dibuat untuk stabilitas negara. Adapun unsur-unsurnya sebagai berikut:

1. Di depan umum

2. Menyatakan atau memberi pernyataan

3. Mengenai perasaan permusuhan, kebencian atau penghinaan/ merendahkan

4. Suatu atau beberapa gologan rakyat Indonesia

Unsur di depan umum tidaklah harus diartikan di tempat-tempat umum atau tempat dengan halayak ramai, akan tetapi termasuk perbuatan yang dapat dilihat atau dengar oleh publik. Meskipun seeorang melakukan perbuatan tidak di tempat umum, akan tetapi menyebabkan dapat di dengar atau dilihat publik, maka unsurnya telah terpenuhi. Adapun unsur menyatakan pada nomor dua tidaklah terbatas pada perkataan, akan tetapi perbuatan yang dapat dinyatakan sebagaimana tulisan atau perbuatan lainnya.

Hal penting yang perlu diperhatikan pada unsur-unsur di atas adalah unsur nomor 3, yaitu mengenai bentuk dari perasaan permusuhan, kebencian dan penghinaan. Menurut Andi Hamzah, undang-undang tidak menerangkan secara rinci bentuknya. Oleh karenanya mengenai penafisran pasal diserahkan kepada hakim yang memeriksa perkara. Tidak adanya kejelasan dalam definisi perbuatan unsur tersebut, terkadang pasal ini menjadi pasal karet.

Turunan pasal 156 adalah 156a yang merupakan sisipan dari UndangUndang PNPS No. 1 tahun 1965. Adapun Pasal 156a berbunyi sebagai berikut:

"Dipidana dengan pidana penjara selama-lamanya lima tahun barang siapa dengan sengaja di muka umum mengeluarkan perasaan atau melakukan perbuatan: a. yang pada pokoknya bersifat permusuhan, penyalahgunaan atau penodaan terhadap suatu agama yang dianut di Indonesia; b. dengan maksud agar supaya orang tidak menganut agama apa pun juga, yang bersendikan Ketuhanan Yang Maha Esa.” 
Yang membedakan pasal 165 dan 165a adalah kekhususan dari objek hukumnya. Pada pasal 156 merujuk kepada golongan masyarakat Indonesia yang dijelaskan jenisnya kepada ras, negeri asal, agama, tempat, asal, keturunan, kebangsaan atau kedudukan menurut hukum tata negara. Adapun pada pasal 165a khusus kepada agama yang di anut di Indonesia.

Problem pada pasal 165a menurut Andi Hamzah adalah perbedaan pemahaman antara pakar hukum mengenai apakah pasal ini kumulatif atau alternatif. Apakah unsur yang terdapat dalam butir a dan $b$ harus terpenuhi atau masing-masing berdiri sendiri. Apabila kumulatif, maka seseorang yang menyerang agama harus dengan maksud supaya orang tersebut tidak beragama. Dalam hal ini, Andi Hamzah setuju dengan pendapat pakar yang menyatakan bahwa pasal 165a adalah alternatif.

Hal penting lainnya adalah berkaitan dengan unsur pada pokoknya bersifat permusuhan, penyalahgunaan atau penodaan terhadap suatu agama yang dianut di Indonesia. Undang-undang tidak menjelaskan tentang bagaimana bentuk dari sifat permusuhan, penyalahgunaan dan penodaan agama, seluruhnya dikembalikan kepada penilaian hakim. Adapun yang dijelaskan undang-undang adalah agama yang dimaksud dalam unsur yaitu Islam,Kristen, Katolik, Hindu, Budha dan Konghuchu. ${ }^{17}$

Dalam memahami hate speech perlu upaya melihat kontektual ujaran supaya secara objektif terlihat tujuan dari sebuah ungkapan. Salah satu upaya melihat sejuah mana bahasa dapat berimplikasi pada penerimaan seseorang dapat didekati dengan teori kebahasaan berupa analisis pragmatik. Yaitu sebuah pendekatan kebahasaan yang tidak hanya mengandalkan teori-teori gramatikal, akan tetapi melihat juga kontekstualnya pada saat ujaran tersebut dikeluarkan.

Pragmatik dalam teori ini adalah studi tentang makna yang berbuhungan dengan situasi ujaran. Prasyarat yang diperlukan dalam menggunakan analisis pragmatis pada tuturan, termasuk yang bermuatan implikatur percakapan adalah situasi uajaran yang meliputi: 1) penutur dan petutur 2) konteks 3) tujuan 4) tindak tutur atau tindak verbal 5) tuturan sebagai produk tindak verbal. ${ }^{18}$

Selain pada Pasal 156 dan 156a adalah terdapat dalam ICCPR Pasal 20 ayat 2 yang berbunyi:

"Segala tindakan yang menganjurkan kebencian atas dasar kebangsaan, ras atau agama yang merupakan hasutan untuk melakukan diskriminasi, permusuhan atau kekerasan harus dilarang oleh hukum.”

Sebagai upaya mencegah penerapan pasal ujaran kebencian tersebut, Perserikatan Bangsa-Bangsa memeberikan batasan sebagai berikut ${ }^{19}$ :

${ }^{17}$ Hamzah, Andi. 2015. Delik-Delik Tertentu (Speciale Delicten) di dalam KUHP. Jakarta: Sinar Grafika. 247-249.

${ }^{18}$ Leech, 1989. Principle of Pragmatics, London: Longman. Hlm. 13.

${ }^{19}$ Simanjuntak, CC Maruli. Tanpa Tahun. Atas Nama Kebencian, Kajian Kasus-Kasus Kejahatan Berbasis Kebencian di Indonesia. Jakarta: Yayasan Bantuan Hukum Indonesia. Hlm. 12. 
a. Harus ada maksud jahat secara umum (public intent) dari hasutan yang menimbulkan kekerasan, permusuhan, diskriminasi;

b. Pembatasan atas kebebasan berekspresi harus jelas, didefinisikan sempit, dan diatur oleh aturan hukum. Lebih jauh pembatasan itu memang perlu dan proporsional terhadap tujuan pembatasan itu sendiri;

c. Pembatasan itu tidak membahayakan pelaksanaan hak itu sendiri, dan merupakan tindakan paling akhir;

d. Persidangan atas kasus pernyataan kebencian tersebut harus dilakukan oleh pengadilan yang independen dan imparsial.

Dalam Undang-Undang No. 39 tahun 1999 tentang Hak Asasi Manusia pasal 6 dijelaskan bahwa dalam mengemukakan pendapat di depan umum, setiap orang berkewajiban dan bertanggung jawab atas hal-hal sebagai berikut:

a. Menghormati hak-hak dan kebebasan orang lain;

b. Menghormati aturan-aturan moral yang diakui umum;

c. Mentaati hukum dan ketentuan peraturan perundang undangan yang berlaku;

d. Menjaga dan menghormati keamanan dan ketertiban umum; dan

e. Menjaga keutuhan persatuan dan kesatuan bangsa

Dalam UU No 40 Tahun 2008 tentang Penghapusan Diskriminasi Ras dan Etnis Pasal 16 berbunyi:

"Setiap orang yang dengan sengaja menunjukkan kebencian atau rasa benci kepada orang lain berdasarkan diskriminasi ras dan etnis sebagaimana dimaksud dalam Pasal 4 huruf b angka 1, angka 2, atau angka 3, dipidana dengan pidana penjara paling lama 5 (lima) tahun dan/atau denda paling banyak Rp 500.000.000,00 (lima ratus juta rupiah)."

Undang-Undang Nomor 11 Tahun 2008 tentang Informasi dan Transaksi Elektronik Pasal 28 ayat (2) berbunyi:

"Setiap Orang dengan sengaja dan tanpa hak menyebarkan informasi yang ditujukan untuk menimbulkan rasa kebencian atau permusuhan individu dan/atau kelompok masyarakat tertentu berdasarkan atas suku, agama, ras, dan antargolongan".

Ketentuan pidana untuk perbuatan di atas terdapat pada Pasal 45 ayat (2) yang berbunyi:

"Setiap Orang yang memenuhi unsur sebagaimana dimaksud dalam Pasal 28 ayat (1) atau ayat (2) dipidana dengan pidana penjara paling lama 6 (enam) tahun dan/atau denda paling banyak Rp.1.000.000.000,00 (satu miliar rupiah).”

Pada peraturan Kapolri nomor SE/06/X/2015 menyatakan pada point f: bahwa ujaran kebencian dapat berupa tindak pidana yang diatur dalam Kitab 
Undang-Undang Hukum Pidana (KUHP) dan ketentuan pidana lainnya di luar KUHP, yang berbentuk antara lain:
a. penghinaan;
b. pencemaran nama baik;
c. penistaan;
d. perbuatan tidak menyenangkan;
e. memprovokasi;
f. menghasut;
g. penyebaran berita bohong;

dan semua tindakan di atas memiliki tujuan atau bisa berdampak pada tindak diskriminasi, kekerasan, penghilangan nyawa, dan/atau konflik sosial. Bahwa ujaran kebencian sebagaimana dimaksud di atas, bertujuan untuk menghasut dan menyulut kebencian terhadap individu dan/atau kelompok masyarakat dalam berbagai komunitas yang dibedakan dari aspek:
a. suku;
b. agama;
c. aliran keagamaan;
d. keyakinan/kepercayaan;
e. ras;
f. antar golongan;
g. warna kulit;
h. etnis;
i. gender;
j. $\quad$ kaum difabel (cacat);
k. orientasi seksual.

Selanjutnya bahwa ujaran kebencian (hate speech) sebagaimana dimaksud di atas dapat dilakukan melalui berbagai media, antara lain:
a. dalam orasi kegiatan kampanye;
b. spanduk atau banner;
c. jejaring media sosial;
d. penyampaian pendapat di muka umum (demonstrasi);
e. ceramah keagamaan;
f. media masa cetak maupun elektronik;
g. pamflet.

Menurut Komisi Nasional Hak Asasi Manusia (KOMNASHAM) menjelaskan alasan kenapa Surat Edara (SE) di atas perlu untuk dikeluarkan. Secara umum ujaran kebencian belum di kenal secara di masyarakat dan belum banyak literur yang membahas tentang masalah tersebut di Indonesia. Pada perkembangannya, saat ini ujaran kebencian sangat marak dalam bentuk lisan maupun tulisan khususnya di dunia maya.

Bahaya dari ujaran kebencian diantaranya adalah merendahkan manusia lain. Dalam konsep negara berdasarkan ketuhanan yang maha esa, tidak menghargai sesama ciptaan tuhan berarti mengabaikan nilai-nilai agama. Selain bertentangan dengan ajaran agama, juga telah menjadi salah satu 
penyebab konflik paling banyak. Dalam sejarahnya, ujaran kebencian telah menjadi salah satu penyebab terjadinya genosida di Negara di Rwanda.

Undang-undang yang menjadi induk dari ujaran kebencian di Indonesia adalah KUHP Pasal 156. Didalamnya menentukan perbuatan dapat dipidana berupa mengungkapkan perasaan permusuhan, kebencian dan penghinaan atas dasar golongan berupa, suku, ras, serta agama. Norma tersebut telah menjadi pembeda dengan norma hukum lain dalam pasal-pasal yang terdapat dalam KUHP.

Merujuk kepada KUHP Pasal 156 sebenarnya merupakan pasal "Haatzai artikelen", sebutan populer untuk sekumpulan delik pidana yang mengancam mereka yang menyebarkan perasaan permusuhan, kebencian, atau pun penghinaan terhadap penguasa negara", mulai diterapkan oleh penguasa Hindia Belanda pada tanggal 15 Maret 1914.

Yang perlu dicermati dari delik ini adalah adanya objek langsung yaitu individu atau kelompok/golongan tertentu. Pada rekomendasi nomor 1805 (2007) Dewan Eropa telah jelas melarang hate speech yang ditujukan kepada individu atau kelompok tertentu atas dasar ras, agama maupun golongan dan memperbolehkan blasphemy yang dilandaskan pada kritik dengan basis akademis.

Pada Undang-Undang Nomor 11 Tahun 2008 tentang Informasi dan Transaksi Elektronik Pasal 28 ayat (2) klausul "Ditujukan untuk menimbulkan rasa kebencian atau permusuhan individu dan/atau kelompok masyarakat tertentu berdasarkan atas suku, agama, ras, dan antar golongan (sara)" merupakan delik hate speech yang objeknya adalah individu atau kelompok masyarakat.

Objek dari tindak pidana hate speech perlu mendapatkan perhatian, karena identitas golongan berupa ras, suku atau agama sangatlah bias tafsir. Masing-masing individu dalam golongan mempunyai pendapat dan pemikiran yang berbeda. Perlu adanya otoritas legal yang dapat menentukan apakah suatu perbuatan dapat menimbulkan rasa kebencian atau permusuhan. Selama ini, ketika ada tindakan hate speech maka kepastian dari implementasi regulasi selalu menjadi tumpul.

Dalam menanggulangi permasalahan hate speech perlu adanya regulasi yang menjamin kepastian tentang tindakan apa saja yang dikatagorikan hate speech. Selama ini berbagai bentuk tindakan hate speech tersebar dalam berbagai regulasi. Adapun yang dainggap cukup lengkap terdapat dalam Peraturan Kapolri nomor SE/06/X/2015 yang bukan undang-undang.

Selain regulasi, diperlukan kebijakan non penal yang terintegrasi dalam memberantas ujaran kebencian. Meliputi seluruh upaya dalam berbagai aspek yang dapat menjamin masalah ujaran kebencian dapat teratasi. Khususnya penyebaran yang saat ini gencar di dunia maya.

\section{E. Hate Speech Dan Kebebasan Berekspresi dalam Formulasi Hukum Islam 1. Formulasi Definisi Hate Speech}


خطاب الكر اهية Dalam bahasa Arab, ujaran kebencian disebut dengan adapun kata كره dalam penggunaannya sangat majemuk. Bisa dikaitkan dengan bahasa, agama maupun ahlak. Sebagaimana dalam hadis yang berbunyi “إسباغ الوضو عإعلى المكاره". Definisi secara bahasa الكره berarti apa yang dibenci manusia dan berusaha memisahkan diri dengannya. ${ }^{20}$

خلق المكروه يوم “ Kata-kata juga diantaranya terdapat dalam hadis الكرم النوم "الثلثاءوخلق النور يوم الآربعاء yang dimaksud makruh dalam hadis tersebut adalah kejelekan. Adapun secara istilah maka kata كره mempunyai hubungan dengan makna sebagai berikut: ${ }^{21}$

1. Kebencian manusia dengan kekuatan terhadap pekerjaan yang tidak mampu dan disukainya

2. كره dimaknai keburukan dan menjadi lawan kata dari yang disukai atau kebaikan

3. كره dimaknai juga menganjurkan manusia kepada kebencian atau hal lain yang merupakan kebalikan dari yang disukai. Atau dengan kata lain memaksa untuk membenci.

4. كر اهية dimaknai hal yang buruk

Dari berbagai pengertian di atas, maka dapat dimengerti tentang definisi “yang dipakai dalam media arab, yaitu menghasut dan menganjurkan kebencian kepada yang lain. Adapun yang perlu di garis bawahi adalah tentang dua hal yang penting dalam ujaran kebencian pertama الحقد و التحريض yaitu kebencian dan hasutan. Al-Hikdu dapat dimaknai sebagai menahan rasa permusuhan dalam hati dan mengeluarkannya pada kesempatan yang tepat. Adapun kata al-Tahrid yaitu menganjurkan orang lain dimana orang tersebut mengetahui penganjurnya. $^{22}$

Dalam Islam membenci sesama adalah suatu perbuatan yang tercela. Sebagaimana terdapat dalam sebuah hadis dari Anas, bahwasanya Rasulullah bersabda:

"Janganlah engkau semua saling benci-membenci, saling dengkimendengki, saling belakang-membelakangi dan saling putusmemutuskan - ikatan persahabatan atau kekeluargaan - dan jadilah engkau semua hai namba- hamba Allah sebagai saudarasaudara. Tidaklah halal bagi seseorang Muslim kalau ia meninggalkan - yakni tidak menyapa - saudaranya lebih dari tiga hari (Muttafaq 'Alaihi). ${ }^{23}$

Diriwayatkan dari Abu Hurairah, bahwasanya Rasulullah bersabda:

${ }^{20}$ Zahroh, Walid Husni. 2014, Inni Ukrihuka, Khitabu al-Karahiyyati wa al-Taifiyyati fillami al- 'Alami al-'Arabiyyati. Yordania: Center For Defending Fredoom of Jurnalists. Hlm. 29.

${ }^{21}$ Zahroh, Walid Husni. 2014, Inni Ukrihuka, Khitabu al-Karahiyyati wa al-Taifiyyati fi Ilami al- 'Alami al-'Arabiyyati. Yordania: Center For Defending Fredoom of Jurnalists. Hlm. 29.

${ }^{22}$ Zahroh, Walid Husni. 2014, Inni Ukrihuka, Khitabu al-Karahiyyati wa al-Taifiyyati fi Ilami al- 'Alami al-'Arabiyyati. Yordania: Center For Defending Fredoom of Jurnalists. Hlm. 30.

${ }^{23}$ Yahya, Abi Zakariya bin Syaraf al-Nawawi. 1987. Riyadu al-Salihin. Mesir: Daru alRayyan li al-Turas. Hlm. 426. 
"Pintu surga dibuka setiap hari Senin dan Kamis. Maka pada hari itu setiap hamba diberi ampunan selama ia tidak menyekutukan Allah dengan sesuatu apapun, kecuali seorang hamba yang bermusuhan dengan saudaranya. Maka dikatakan, 'Akhirkan dulu mereka hingga mereka akur, akhirkan dulu mereka hingga mereka akur, akhirkan dulu mereka hingga mereka akur, akhirkan dulu mereka hingga mereka akur" (HR. Muslim). ${ }^{24}$ bersabda:

Dari Abdullah bin 'Amr bin Ash RA. ia berkata: Rasulullah Saw.

"Orang Islam adalah kaum mukminin yang terhindar dari gangguan lidah dan tangannya; sedangkan orang yang hijrah adalah orang yang meninggalkan segala apa yang dilarang Allah" (Muttafaq 'alaihi). ${ }^{25}$

Selain larangan untuk membenci sesama umat Islam, sifat rahmatan lil'alamin juga berlaku bagi umat yang lain. Hal tersebut sebagaimana dalam al Quran disebutkan: "Dan janganlah sekali-kali kebencian (ти) kepada sesuatu kaum karena mereka menghalang-halangi kamu dari Masjidil haram, mendorongmu berbuat aniaya (kepada mereka)" (Al-Maidah ayat 2). Pada ayat lain diterangkan "Dan janganlah sekali-kali kebencianmu terhadap sesuatu kaum, mendorong kamu untuk berlaku tidak adil. Berlaku adillah, karena adil itu lebih dekat kepada takwa" (Al Maidah ayat 8). Selain itu terdapat ayat "Ataukah mereka dengki kepada manusia (Muhammad) lantaran karunia yang Allah telah berikan kepada manusia itu?" (Al-Nisa': 54).

Berkaitan dengan hate speech, maka kebencian yang dilarang dalam Islam termasuk perkataan buruk yang dapat menyakiti orang lain. Adapun diantara ayat-ayatnya adalah sebagai berikut:

\section{Al- Anam ayat 108}

Dan janganlah kamu memaki sembahan-sembahan yang mereka sembah selain Allah, Karena mereka nanti akan memaki Allah dengan melampaui batas tanpa pengetahuan. Demikianlah kami jadikan setiap umat menganggap baik pekerjaan mereka. Kemudian kepada Tuhan merekalah kembali mereka, lalu dia memberitakan kepada mereka apa yang dahulu mereka kerjakan.

\section{Al- Qolam ayat 10-11}

10. Dan janganlah kamu ikuti setiap orang yang banyak bersumpah lagi hina,

11. Yang banyak mencela, yang kian ke mari menghambur fitnah.

${ }^{24}$ Yahya, Abi Zakariya bin Syaraf al-Nawawi. 1987. Riyadu al-Salihin. Mesir: Daru alRayyan li al-Turas. Hlm. 426.

${ }^{25}$ Yahya, Abi Zakariya bin Syaraf al-Nawawi. 1987. Riyadu al-Salihin. Mesir: Daru alRayyan li al-Turas. Hlm. 425. 


\section{Al-Hujrat ayat 11 dan 12}

Hai orang-orang yang beriman, janganlah sekumpulan orang lakilaki merendahkan kumpulan yang lain, boleh jadi yang ditertawakan itu lebih baik dari mereka. dan jangan pula sekumpulan perempuan merendahkan kumpulan lainnya, boleh jadi yang direndahkan itu lebih baik. dan janganlah suka mencela dirimu sendiri dan jangan memanggil dengan gelaran yang mengandung ejekan. Seburuk-buruk panggilan adalah (panggilan) yang buruk sesudah iman dan barangsiapa yang tidak bertobat, Maka mereka Itulah orang-orang yang zalim.

Hai orang-orang yang beriman, jauhilah kebanyakan purbasangka (kecurigaan), Karena sebagian dari purba-sangka itu dosa. dan janganlah mencari-cari keburukan orang dan janganlah menggunjingkan satu sama lain. Adakah seorang diantara kamu yang suka memakan daging saudaranya yang sudah mati? Maka tentulah kamu merasa jijik kepadanya. dan bertakwalah kepada Allah. Sesungguhnya Allah Maha Penerima Taubat lagi Maha Penyayang.

Dalam tafsir al-Manar dijelaskan bahwa الإحتقار bermakna الإسخار berarti mencela dan melaknat dengan maksud menyakiti. اللمز dilakukan dengan perkataan adapun التنابز dilakukan dengan perbuatan. Terkahir adalah yaitu panggilan yang tidak pantas, dimana manusia yang mendengarnya merujuk kepada sesuatu yang buruk/jelek. ${ }^{26}$

\section{Al-Nisa ayat 148}

Allah tidak menyukai Ucapan buruk, (yang diucapkan) dengan terus terang kecuali oleh orang yang dianiaya. Allah adalah Maha mendengar lagi Maha Mengetahui.

\section{Al-Nuur ayat 19}

Sesungguhnya orang-orang yang ingin agar (berita) perbuatan yang amat keji itu tersiar di kalangan orang-orang yang beriman, bagi mereka azab yang pedih di dunia dan di akhirat. dan Allah mengetahui, sedang, kamu tidak Mengetahui.

\section{Al-Humazah ayat 1}

Kecelakaanlah bagi setiap pengumpat lagi pencela.

\section{Ibrohim ayat 24 dan 26}

24. Dan mereka diberi petunjuk kepada ucapan-ucapan yang baik dan ditunjuki (pula) kepada jalan (Allah) yang Terpuji.

\footnotetext{
${ }^{26}$ Imamuddin Abi al-Fida Isma'il Ibnu Kasir. 2000. Tafsir al-Qur'an al- 'Adim. Jilid 13.
} Yaman: Mu'assasah Qurtubah. Hlm. 154. 
26. Dan perumpamaan kalimat yang buruk seperti pohon yang buruk, yang Telah dicabut dengan akar-akarnya dari permukaan bumi; tidak dapat tetap (tegak) sedikitpun.

\section{Al-Qasas ayat 55}

Dan apabila mereka mendengar perkataan yang tidak bermanfaat, mereka berpaling daripadanya dan mereka berkata: "Bagi kami amalamal kami dan bagimu amal-amalmu, kesejahteraan atas dirimu, kami tidak ingin bergaul dengan orang-orang jahil".

\section{Al-Ahzab ayat 70}

Hai orang-orang yang beriman, bertakwalah kamu kepada Allah dan Katakanlah perkataan yang benar.

\section{Yunus ayat 99}

Dan Jikalau Tuhanmu menghendaki, tentulah beriman semua orang yang di muka bumi seluruhnya. Maka apakah kamu (hendak) memaksa manusia supaya mereka menjadi orang-orang yang beriman semuanya?

Menurut Ibrahim Toha Ziyad dalam tesisnya membagi bentuk penghinaan kepada tiga hal sebagai berikut ${ }^{27}$ :

1. Al-Zammur. menisbahkan suatu hal kepada orang lain dalam bentuk sindiran yang dapat menimbulkan kemarahan.

2. Al-Qadhu. sesuatu yang berhubungan dengan reputasi dan harga diri dengan tidak menisbahkan sesuatu kepada orang lain.

3. Al-Tahkir: setiap celaan yang mengindikasikan adanya hinaan dan pelecehan.

Menurut Garib Ahmad, dalam undang-undang pidana Mesir membedakan perbuatan penghinaan kepada tiga tindakan ${ }^{28}$ :

1. Al-Ihanah: Setiap ucapan dan perbuatan yang dianggap oleh kebiasaan terdapat unsur hinaan dan penyerangan terhadap harkat martabat dalam pandangan manusia.

2. Al-Qadaf: menisbatkan atau menuduhkan kepada seseorang atas suatu perbuatan yang tercela.

3. Al-subbu: secara bahasa adalah kutukan. Yaitu setiap hinaan yang tidak termasuk tuduh atas tindakan dan peristiwa yang nyata, akan tetapi menempelkan sifat atau aib kepada seseorang.

Dalam Islam, formulasi tindakan hate speech melebihi cakupan dalam definisi regulasi maupun istilah Barat. Asas moral yang mendasari hate speech berlaku bagi tindakan lain yang berkaitan dengan kemaslahatan umat. Pertama larangan untuk membenci orang lain, sesama muslim ataupun non muslim. Secara subjektif seorang muslim dilarang

${ }^{27}$ Ibrahim Toha Ziyad. 2011. Nitaq al_Masuliyyah al-Jazaiyyah 'an Jara'imi al-Dammi wa al-Qadhi wa al-Tahqiri. Turky: Middle East University. Hlm. 36.

${ }^{28}$ Garib Ahmad, Jaraim al-Ihanah wa al-Qadaf wa al-Sub, Mesir: al-Niyabah al-Idariyah. 
untuk memiliki perasaan hasad ataupun melakukan tindakan atas kebenciannya kepada orang lain. Adapun dari sudut objektif, maka tindakan apapun yang menyakiti orang lain dilarang oleh agama.

Kedua spesifik hate speech, maka berkaitan dengan larangan perkataan yang dapat menimbulkan permusuhan pribadi maupun kelompok. Termasuk perkataan dan perbuatan tersebut yang ditujukan kepada seorang muslim atau non muslim. Tidak ada perbedaan status dalam melihat ciptaan tuhan, Islam melarang diskriminasi atas dasar apapun terutama terhadap sesama muslim. Islam sangat menjungjung tinggi hak asasi manusia dengan dasar penghargaan atas perbedaan. Hal tersebut sebagaimana terdapat dalam surat al-Hujraat ayat 13.

\begin{tabular}{|c|c|}
\hline $\begin{array}{l}\text { Tindakan Ujaran Kebencian dalam } \\
\text { Teori dan Regulasi }\end{array}$ & $\begin{array}{l}\text { Tindakan Ujaran } \quad \text { Kebencian } \\
\text { dalam Islam }\end{array}$ \\
\hline 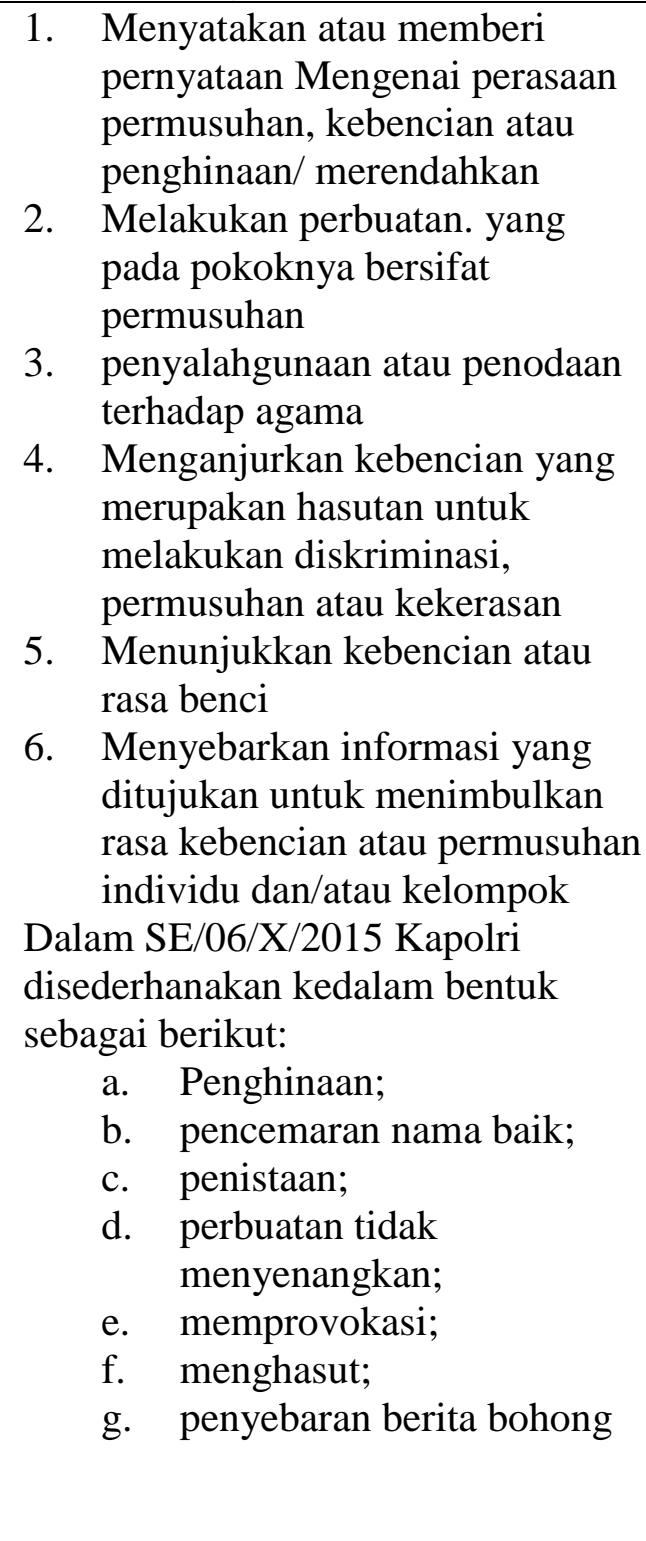 & $\begin{array}{l}\text { 1. Al-Hikdu dapat dimaknai } \\
\text { sebagai menahan rasa } \\
\text { permusuhan dalam hati dan } \\
\text { mengeluarkannya pada } \\
\text { kesempatan yang tepat } \\
\text { (Dengki) } \\
\text { 2. al-Tahrid yaitu menganjurkan } \\
\text { orang lain dimana orang } \\
\text { tersebut mengetahui } \\
\text { penganjurnya (menghasut) } \\
\text { 3. Iskhor yaitu menghina dan } \\
\text { menganggap remeh. } \\
\text { 4. Al-lumzuberarti mencela dan } \\
\text { melaknat dengan maksud } \\
\text { menyakiti. } \text { Al-lumzu } \\
\text { dilakukan dengan perkataan } \\
\text { adapun } \text { Al-himazu dilakukan } \\
\text { dengan perbuatan. } \\
\text { 5. Al-Tanabuz yaitu panggilan } \\
\text { yang tidak pantas, dimana } \\
\text { manusia yang mendengarnya } \\
\text { merujuk kepada sesuatu yang } \\
\text { buruk/jelek } \\
\text { 6. Al-Zammu. menisbahkan suatu } \\
\text { hal kepada orang lain dalam } \\
\text { bentuk sindiran yang dapat } \\
\text { menimbulkan kemarahan. } \\
\text { 7. Al-Qadhur. sesuatu yang } \\
\text { berhubungan dengan reputasi } \\
\text { dan harga diri dengan tidak } \\
\text { menisbahkan sesuatu kepada } \\
\text { orang lain. }\end{array}$ \\
\hline
\end{tabular}




\begin{tabular}{|l|l|}
\hline $\begin{array}{l}\text { 8. Al-Tahkir. setiap celaan yang } \\
\text { mengindikasikan adanya } \\
\text { hinaan dan pelecehan. }\end{array}$ \\
$\begin{array}{ll}\text { 9. Hammazun Masyaun } \\
\text { binamimin, yang suka mencela } \\
\text { dan menebar fitnah } \\
\text { permusuhan }\end{array}$ \\
\hline
\end{tabular}

\section{Hate Speech dan Kebebasan Berekspresi dalam Islam}

Sebagai agama rahmatan lil'alamin, Islam berisi ajaran universal yang menjunjung tinggi nilai kemanusiaan dan perlindungan hak asasi manusia. Hak asasi manusia di dunia Islam bukanlah hal yang baru, syariat Islam yang universal mengajarkan prinsip-prinsip persamaan hak asasi dan kebebasan, termasuk kebebasan berekspresi. ${ }^{29}$

Dalam konteks hak asasi manusia, hate speech merupakan pembatasan terhadap kebebasan berekspresi. Menurut Mohammad Hasyim Kamali terkait dengan kebebasan berekspresi, sesungguhnya Islam merujuk kepada deklarasi hak asasi manusia pada pasal 19 yang menyatakan bahwa setiap orang tidak boleh dibatasi dalam mengekspresikan dan mencari pengetahuan. Hanya saja yang menjadi pertanyaan, apakah kebebasan itu tidak ada batasan sama sekali ataukah ada?. Dalam perkembangannya, para pembela demokrasi belum bersepakat akan pengertian batasan kebebasan berekspresi.

Inklusifitas menjadi sesuatu yang penting dalam kebebasan berekspresi, yaitu merupakan langkah untuk keluar dari batasan agar individu dan komunitas dapat berinteraksi dengan yang lain. Antar individu harus menghormati pendapat dan pikiran yang keluar atas dasar kebebasan berpendapat. Tidak ada yang dapat menghakimi sebuah pikiran maupun keyakinan seseorang. Akan tetapi ketika tindakan tersebut melanggar hak orang lain, maka regulasi hak asasi manusia telah menetapkan pembatasan.

Menurut Hasyim Kamali, bagian penting dari pembatasan kebebasan berekspresi adalah penghinaan terhadap agama. Dalam Islam faktanya tidak ada hukuman had bagi orang yang menghina agama, sehingga harus menggunakan pendekatan takzir. Begitupun dengan hukuman mati, maka tidak dapat diterapkan bagi seorang yang menghina agama. Hukuman mati merupakan had bagi orang yang murtad maupun hirabah. Dalam rangka membatasi hal-hal yang bersifat interpersonal maupun impersonal tersebut maka Islam menetapkan etika dalam pergaulan. $^{30}$

${ }^{29}$ Candra Perbawati, "Penegakan Hak Asasi Manusia di Era Globalisasi dalam Perspektif Hukum Islam” dalam al-'Adalah Vol. XII, No. 4, Desember 2015.

${ }^{30}$ Kamali, Mohammad Hashim. Ethical Limits on Freedom of Expression with Special Reference to Islam. Cile Journal Qatar. 2014. Hlm. 40-41. 
Agama dan nilai atau etik mempunyai hubungan yang erat, akan tetapi keyakinan suatu agama sangatlah sulit untuk bersanding dengan yang lain. Meskipun begitu, norma etik antara satu pengikut agama dengan yang lain sering mempunyai kemiripan. Moralitas sebagai basis tidak dapat eksis tanpa agama, meskipun moralitas yang dipraktekan tidak harus selalu terkait dengan religiositas. Sehingga setiap transformasi moralitas, juga diawali dengan pembaruan agama.

Islam sangat berkomitmen terhadap kebijaksanaan moral, kasih sayang, karakter kejujuran dan keadilan. Secara langsung manusia diamanahi untuk menjadi khalifah di muka bumi untuk menegakan keadilan. Dalam Alquran terdapat beberapa konsep etika ma'ruf, al-khair, al-birr, al-haq, al-qist, ihsan and șalihat. Lain dari itu ada amal m'aruf nahi munkar (hisbah), ta'awun, ukhuwah, humanisasi, dan upaya mensejahterakan sosial. Adapun yang paling utama adalah sabar dan hilm. ${ }^{31}$

Islam tidak membedakan kedudukan manusia atas dasar apapun kecuali berdasarkan ketakwaan. Keimanan dan berbuat baik merupakan kalimat yang selalu diulang-ulang dalam Alquran sampai 50 kali. Hal itu menegaskan bahwa agama dan moral harus selalu berjalan beriringan, sehingga hukum Islam merupakan suprastruktur dari norma etik. Bagi ilmuan muslim, hukum dan etika semua bersumber pada kewajiban moral. $^{32}$

Pembagian antara hukum dan etika dalam Islam tidaklah terlalu jelas. Banyak batasan hukum syariah yang langsung membatasi kebebasan berekspresi sebagaimana larangan mengumpat, menghina, fitnah, penodaan agama, menyebut muslim dengan kafir, dan ikut serta dalam pelanggaran moral. Namun, di luar ini pelanggaran hukum sebagian besar ajaran Islam berkaitan dengan kebebasan berbicara dan berekspresi adalah dari impor etika. Yaitu ditujukan kepada hati nurani seseorang untuk tidak menyakiti orang lain. Termasuk dalam ini berbohong, mengejek orang lain dan menyebut mereka dengan nama ofensif, kata merendahkan, fitnah, spionase dan pidato menyakitkan, baik dalam kehadiran mereka atau di belakang mereka, ditujukan kepada individu atau kelompok individu dan masyarakat. $^{33}$

Dalam memformulasikan ketentuan hukum suatu perbuatan, harus merujuk kepada tujuan syariat/ maqasid al-syari'ah. Tindak pidana hate speech yang beririsan langsung dengan kebebasan berekspresi perlu dibatasi. Konsep maqasid al-syari'ah berupa perlindungan terhadap harkat, martabat dan hak asasi manusia menjadi dasar kemaslahatan pembatasan tersebut. Dalam teori Hak Asasi Manusia (HAM) pembatasan terhadap

${ }^{31}$ Kamali, Mohammad Hashim. Ethical Limits on Freedom of Expression with Special Reference to Islam. Cile Journal Qatar. 2014. Hlm. 45.

${ }^{32}$ Kamali, Mohammad Hashim. Ethical Limits on Freedom of Expression with Special Reference to Islam. Cile Journal Qatar. 2014. Hlm. 46.

${ }^{33}$ Kamali, Mohammad Hashim. Ethical Limits on Freedom of Expression with Special Reference to Islam. Cile Journal Qatar. 2014. Hlm. 48. 
kebebasan dapat dilakukan apabila bertentangan dengan hak asasi manusia orang lain ataupun demi menjaga keamanan dan moral publik.

\section{Formulasi Hukum Islam tentang Hate Speech}

\section{a. Pendekatan Takzir}

Hate speech dalam formulasi hukum Islam masuk dalam pembahasan hukum pidana atau Jinayah. Konsep kejahatan dalam Fiqih Jinayah terbagi dalam tiga katagori berdasarkan kualitas berat ringannya hukuman. Yaitu Jarimah dengan hukuman berupa hadud, qisas diyat dan takzir. ${ }^{34}$

Menurut Zuhaeli perkataan yang dapat menyakiti seseorang muslim adalah dihukum takzir. Sebagai contoh mengatai seseorang dengan kata-kata ya fasiq, ya kafir, ya fajir, hai peminum arak, hai pemakan riba. Suatu saat Sayyidina Ali Karamallahu Wajhah ditanya tentang perkataan laki-laki kepada lainnya "ya fasiq, ya khabis" berkata Sayyida Ali" itu semua fawahisy dan dilamnya ada takzir dan bukan had. dijelaskan ${ }^{36}$ :

Dalam sebuah hadis dalam kitab Riyadhu al-Shalihin عن ابن عمررضي الله عنهماقال: قال رسول الله صلي الله عليه وسلم: إذاقال الرجل لأخيه:

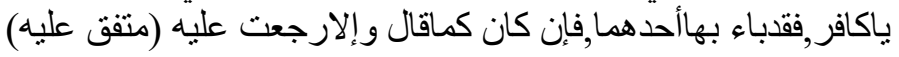

Artinya: dari Ibnu 'Umar RA berkata: Rasulullah Saw bersabda: apabila ada seseorang berkata kepada saudaranya hai kafir, maka sebutan tersebut akan menimpa salahsatunya. Jika perkataan itu benar maka akan menimpa orang yang dituduh, jika tidak maka kekafiran kembali kepada yang menuduh (Muttafaqun 'alaih).

\section{و وعن أبي ذر رضي الله عنه أنه سمع رسول الله صلي الله عليه وسلم يقول: من دعارجلا بالكفر, أوقال:عدو الله, وليس كذاللك إلاححار عليه (متفق عليه)}

Artinya: dari Abi Dzar RA bahwa dirinya mendengar Rasulullah Saw bersabda: Siapa yang menyeru kepada seseorang dengan sebutan kekafiran atau ia mengatakan: Wahai musuh Allah, sementara yang dituduhnya itu tidak demikian maka sebutan tersebut kembali kepadanya (Muttafaqun 'alaih).

Adapun perkataan seperti "hai Anjing, hai Babi atau hai Khimar tidak di takzir menurut pendapat ulama hanafiyah. Dikarenakan menuduh atas sesuatu yang bukan bentuknya, maka dimasukan kepada berbohong. Adapun yang lain tetap ditakzir selama

${ }^{34}$ Machrus Munajat, "Pengaturan Tindak Pidana dalam Islam Berdasarkan Teori Maqasid Al-Syari'ah", dalam Jurnal Asy-Syir'ah, Vol. 45, No. I, 2011. Hlm. 1108.

${ }^{35}$ Zuhaili, Wahbah. 1985. Al-fiqhu al-Islami wa adillatuhu. Damaskus: Darul Fikr. Hlm. 197-198.

${ }^{36}$ Yahya, Abi Zakariya bin Syaraf al-Nawawi. 1987. Riyadu al-Shalihin. Mesir: Daru alRayyan li al-Turas. Hlm. 426. 
perkataan tersebut menyakiti. Menurut Imam Syafi'ai setiap perkataan "ya kafir, ya fasiq, ya syaqi, ya kalb, ya himar, ya taias, ya rafidI, ya khabis, ya kazzab, ya qawad, ya dayus" maka harus ditakzir. Yaitu berdasarkan ketetapan dari seorang pemimpin, bisa dengan pukulan atau penjara atau dengan cercaan/ cacian. Lainnya model-model hukuman yang dapat mencegah kejahatan dan sesuai dengan keadaan manusia. ${ }^{37}$

Menurut 'Abdul Qodir Audah jarimah takzir merupakan perbuatan pidana yang dapat dihukum dengan hukuman tunggal atau lebih berdasarkan takzir. Takzir sendiri bermakna takdib atau pendisiplinan. Menurut Audah, syariah tidak memberikan batasan tentang hukuman bagi jarimah takzir. Hukuman takzir yang diputuskan hakim bisa didasarkan pada kepantasan atas dasar perbuatan dan pelaku. Sehingga hukuman takzir sesungguhnya tidak terukur. ${ }^{38}$

Pada perbuatan yang dapat dihukumi takzir dapat bersumber dari nas Alquran maupun kebijakan penguasa. Contoh yang bersumber dari nas adalah diharamkannya riba, hianat, suap dan perbuatan lain. Yang membedakan ketentuan perbuatan yang telah ada di nas adalah kelaziman dan keberlanjutan dari larangan tersebut. Adapun pebuatan yang dilarang berdasarkan kebijakan penguasa, maka harus disesuaikan dengan kebutuhan masyarakat sehingga dapat berubahubah.

Menurut Alfitri takzir meliputi seluruh dosa yang dianggap membahayakan keamanan negara dan bertentangan dengan tatanan publik. Bisa berkaitan dengan hal yang mengganggu sistem sosial maupun politik. Sebagaimana qisas, takzir juga berkaitan dengan hakhak individual. Sehingga seorang yang menjadi korban dapat meminta negara untuk memaafkan. Dengan pertimbangan tersebut negara dapat menghukum atau tidak menghukum. ${ }^{39}$

Menurut 'Audah, yang membedakan takzir dengan hukuman lain (hudud dan kisas) diantaranya adalah pada pengampunan atas perbuatan seseorang. Pada jarimah takzir pengampunan berada di tangan penguasa dengan syarat tidak melanggar hak asasi korban. Sebaliknya, ketika korban memberikan maaf kepada seorang pelaku maka hanya berkaitan dengan hak dasarnya, selebihnya adalah dikembalikan kepada penguasa. Adapun ketika perbuatan pidana berkaitan dengan kepentingan umum, maka tidak ada pengampunan kecuali peringanan pemidanaan.

${ }^{37}$ Zuhaili, Wahbah. 1985. Al-fiqhu al-Islami wa Adillatuhu. Damaskus: Daru al-Fikr. Hlm. 197-198.

${ }^{38}$ Audah, Abdul Qodir. Tanpa Tahun. al-Tasyri' al-Jina'I Muqaronan bi al-Qanuni Al Wad'i. Bairut: Daru al-Kutub al-'Arabi. Hlm. 80.

${ }^{39}$ Alfitri, "Konflik Hukum Antara Ketentuan Hukum Pidana Islam dan Hak-Hak Sipil? (Telaah Konsep HAM dan Implementasi Ratifikasi ICCPR dan CAT di Indonesia)" dalam Jurnal Konstitusi, Volume 7, Nomor 2, April 2010, hlm. 107. 
Selain pemaafan adalah kekuasaan hakim dalam melaksanakan aturan. Pada hudud, hakim tidak dapat memilih kecuali ketentuan yang telah ditetapkan. Pada kisas maka ketika ada pemafaan dari korban tapi tidak sepenuhnya maka hakim dapat mengganti dengan diyat. Adapun apabila dimaafkan sepenuhnya maka hukuman diganti dengan takzir. Pada takzir, kewenangan hakim sangatlah luas, dapat menentukan batasan paling bawah atau paling tinggi dari sebuah hukuman, tergantung kepada kondisi perbuatan dan pelaku. ${ }^{40}$

Para ulama sendiri berbeda pendapat tentang batasan paling bawah dan atas untuk takzir. Menurut Hanafiyah paling sedikit adalah tiga kali cambukan karena dibawah itu tidak akan berbekas. Adapun untuk batas maksimal maka dikembalikan kepada kemaslahatan. Sebagai contoh adalah hukuman bagi peminum arak yang telah melakukan untuk ke empat kalinya dan contoh lainnya pada masa rasulullah. $^{41}$

Dalam hukum pidana Islam, bentuk hukuman tidaklah tunggal. Menurut Otto Yudianto, tidak hanya dikenal sanksi pidana atau straf, lain dari itu adalah bentuk sanksi pidana berupa tindakan atau matregel. Dalam hukum pidana umum disebut dengan istilah double track sistem. Konsep ini dapat memperluas kewenangan hakim dalam menentukan hukuman berdasarkan tujuan syara, ${ }^{42}$

Ujaran kebencian dalam definisi yang telah diformulasikan, mencakup tindak pidana yang dianggap ringan sampai berat didasarkan pada akibat yang ditimbulkan. Pada ujaran kebencian yang bersifat serangan individu yang tidak serius, hukuman berupa tindakan dainggap lebih tepat dalam mencapai kemaslahatan. Berbeda ketika tindakan yang dilakukan dapat berdampak sistemik, sehingga menimbulkan kemudaratan yang luas, hukuman berupa pidana menjadi dapat menjadi solusi.

\section{b. Pendekatan Maqasid Al-syari'ah}

Ketika hukuman takzir didasarkan pada pertimbangan kemaslahatan maka diperlukan landasan teoritis yang mendasari formulasi hukum bagi ujaran kebencian. Merujuk kepada ujaran kebencian yang berbatasan langsung dengan kebebasan berekspresi, perlu analisa dari perspektif kemaslahan umum atas dasar kepentingan publik. Hemat penulis, pendekatan yang paling tepat adalah maqasid al-syari'ah.

${ }^{40}$ Audah, Abdul Qodir. Tanpa Tahun. al-Tasyri' al-Jina'I Muqaronan bi al-Qanuni Al Wad'i. Bairut: Daru al-Kutub al-'Arabi Hlm. 80-81.

${ }^{41}$ Bakar, Ibnu Zayd Abdullah. 1415. Al-hudud wa alTa'zirat 'Inda Ibnu al-Qayyim. Dirasatun wa Muwazanatun. Riyad: Daru al-'atiyah. Hlm. 461.

42 Otto Yudianto, "Eksistensi Pidana Penjara Dalam Perspektif Hukum Islam Dan Hukum Adat (Kajian Pembaharuan Hukum Pidana), dalam Jurnal Ilmu Hukum, Volume 8, Nomor 13, Februari 2012, Hlm. 20-27. 
Maqasid al-syari'ah yang dimaksud tidak hanya terbatas kepada pengetahuan tentang maslahat dalam ushul fiqh. Akan tetapi maqashid dijadikan sebagai metode istinbat hukum/ metode berijtihad dalam menetapkan hukum syara'. Menurut Ahmad Imam Mawardi, dua hal penting yang perlu diketahui yaiu bagaimana mengetahui maqasid dari ketetapan syariat, dan bagaimana berijtihad dengan menggunakan maqasid.

Menurut para ulama terdapat lima cara untuk mengetahui maqasid, pertama dengan menegaskan apa yang terdapat dalam Alquran dari tujuan syariat baik yang eksplisit maupun implisit. Kedua, menegaskan ketentuan-ketentuan dalam hadis. Ketiga, isitqra' atau menggunakan metode deduktif. Keempat, menggunakan logika. Adapun menurut Ibnu Asyur maka yang paling utama dalam menemukan maqasid adalah dengan metode istiqra'.

Menurut Ahmad Imam Mawardi terdapat tiga metode ketika seseorang menggunakan maqasid sebagai perangkat ijtihad. Pertama, kaidah berfikir secara maqasid. Kedua, mengatahui hubungan maqasid dengan ushul fiqh. Ketiga, hubungan maqasid dengan qawa'id alfiqhiyah. Ketiga metode tersebut digunakan untuk memastikan bahwa dalam menggunakan maqasid tidak meninggalkan sama sekali metodemetode dalam ushul fiqh maupun fiqih, akan tetapi saling menguatkan. ${ }^{43}$

Problem ujaran kebencian yang menjadi fokus bahasan mendapatkan pendekatan yang tepat dengan menggunakan maqasid alsyari'ah. Maraknya ujaran kebencian yang berlindung pada kebebasan berekspresi harus dilihat dari sudut kemaslahan umum. Apakah perbuatan-perbuatan tersebut mendatangkan kemaslahatan atau justru kerusakan dan perpecahan. Maqasid sendiri menempatkan kemaslahatan sebagai tujuan akhir dari disyari'atkannya hukum Islam. Munurut al-Syatibi maqasid menempatkan maslahat sebagai unsur esensial bagi tujuan-tujuan hukum. ${ }^{44}$

Sebagai ukuran dalam menjelaskan kemaslahatan umum, dalam teori maqasid maka dikenal dengan dimensi dan pembagian. Menurut al-Syatibi, dimensi maqasid terbagi dalam tiga gradasi, yaitu dlaruriyat, tahsiniyyat dan hajiyyat. Daruriyyat terbagi dalam lima hal yaitu hifzual-din (menjaga agama), hifzual-nafs (menjaga jiwa), hifzu al-'aql (menjaga akal), hifzu al-nasl (menjaga keturunan), dan hifzu al-mal (menjaga harta).

Al-Gazali dan al-Syatibi menambahkan kemaslahatan tersebut dengan hifzu al'ird (menjaga kehormatan). Hasyim Kamali memasukan keadilan, hak-hak dasar, kebebasan dan persamaan. Ibnu Asyur mengusulkan kemaslahatan dalam maqasid adalah memelihara

${ }^{43}$ Rokhmad, Abu. 2002. Ushul Fiqh Metodologi Ijtihad Hukum Islam. Semarang: CV. Varos Mitra Utama. Hlm. 20-21.

${ }^{44}$ Rokhmad, Abu. 2002. Ushul Fiqh Metodologi Ijtihad Hukum Islam. Semarang: CV. Varos Mitra Utama. Hlm. 215. 
keteraturan, kesetaraan, kebebasan, kemudahan dan fitrah. Muhammad al-Gazali memasukan kesetaraan, hak asasi manusia, keadilan dan kebebasan dalam maqasid tingkat daruriyyat. Adapun Yusuf alQarḍawi menyimpulkan maqasid umum adalah menjaga keyakinan yang benar, menjaga harkat dan hak asasi manusia, menyeru manusia untuk beribadah kepada Allah Swt, menyucikan jiwa, memperbaiki moral dan menciptakan keharmonisan rumah tangga. Memperlakukan wanita dengan adil, membangun bangsa muslim yang kuat dan menyeru kepada dunia yang koperatif. ${ }^{45}$

Unsur kemudaratan tindakan ujaran kebencian yaitu menyakiti perasaan individu maupun publik. Sasaran hak yang diserang adalah kehormatan dan martabat kemanusiaan. Akibat yang dapat ditimbulkan selain permusuhan adalah disintegrasi, perpecahan dan konflik. Dalam mewujudkan kemaslahatan berupa perlindungan hak asasi manusia perdamaian, kerukunan, toleransi dan kehidupan yang harmonis. Selain menggunakan pendekatan takzir (hukum pidana) juga kebijakan sosial, politik, ekonomi maupun budaya.

Dalam kerangka kerukunan umat beragama di Indonesia, kepentingan publik umat Islam sangat berkaitan dengan the other. Menurut Fawaizul Umam kata tersebut diambil dari definisi postcolonial studies. Merujuk kepada ego sentrisme yang menganggap diri lebih unggul dari yang lain. Konsekuensinya akan ada jarak antara subjek dan objek berupa separasi, oposisi dan alineasi. ${ }^{46}$ Perlu adanya pendekatan komprehensif untuk mewujudkan kemaslahatan sesuai tujuan syariat.

\section{Kesimpulan dan Penutup}

Definisi tentang hate speech dan cakupannya masih menjadi perdebatan berdasarkan pendapat para ahli maupun regulasi. Merujuk kepada regulasi, hate speech adalah tindakan menyatakan perasaan permusuhan, kebencian atau penghinaan terhadap suatu atau beberapa golongan rakyat Indonesia di muka umum. Definisi tersebut belum ditemukan dalam terminologi hukum pidana Islam secara formal, akan tetapi terdapat dalam perbuatan-perbuatan yang secara parsial dilarang.

Perbuatan yang dilarang didasarkan pada ayat-ayat Alquran maupun hadis adalah perbuatan membenci sesama umat Islam maupun non muslim. Selanjutnya berkaitan dengan perkataan buruk berupa fitnah, ujaran maupun hasutan dalam bentuk lisan maupun perbuatan yang dapat menyakiti perasaan orang lain. Termasuk diantaranya adalah mengkafirkan sesama muslim, menodai agama dan menghina dengan kata-kata kotor.

\footnotetext{
${ }^{45}$ Rokhmad, Abu. 2002. Ushul Fiqh Metodologi Ijtihad Hukum Islam. Semarang: CV. Varos Mitra Utama. Hlm. 20.

${ }^{46}$ Fawaizul Umam, "Memaknai Keberagaman: the Other dalam Kontruksi Sosial Elit Kelompok-Kelompok Kegamaan di Kota Mataram”, dalam Jurnal Theologia — Volume 27, Nomor 2, Desember 2016, hlm. 368.
} 
Dalam formulasi hukum pidana Islam, hate speech dihukum takzir. Berdasarkan tindakan dan akibat yang bervariasi, hukuman takzir untuk pelaku jarimah ini adalah dengan tindakan dan pidana (double track system). Hukuman tersebut didasarkan kepada kemaslahatan yang diinginkan syariat (maqasid al-syari'ah). Yaitu perlindungan terhadap martabat dan hak asasi manusia dengan tujuan tercipta kehidupan yang damai, rukun dan harmonis. Selain pendekatan takzir penanggulangan hate speech perlu komprehensif. Yaitu dengan pendekatan sosial, politik, ekonomi maupun budaya.

\section{Daftar Jurnal}

\section{DAFTAR PUSTAKA}

Alfitri, "Konflik Hukum Antara Ketentuan Hukum Pidana Islam dan Hak-Hak Sipil? (Telaah Konsep HAM dan Implementasi Ratifikasi ICCPR dan CAT di Indonesia)" dalam Jurnal Konstitusi, Volume 7, Nomor 2, April 2010.

Brison, Susan J. "The Autonomy Defense of Free Speech" dalam Chicago Journals. Volume 108, Nomor 2, The University of Chicago. 1998.

Britt, Brian M. Curses Left and Right: Hate Speech and Biblical Tradition. Journal of the American Academy of Religion. Volume 78, Nomor 3. Oxford University Press. 2010.

Cohen, Joshua, "Freedom of Expression", dalam Philosophy \& Public Affairs Volume 22, Nomor 3, Summer, 1993, Hlm. 207-263. Stable URL: http://www.jstor.org/stable/2265305. Accessed: 11-05-2016 15:09 UTC 
Fisch, Willian B. Hate Speech in the Constitutional Law of the United States. The American Journal of Comparative Law Volume 50. American Society of Comparative Law. 2002. Stable URL:http://www.jstor.org/stable/840886. Accessed: 11-05-2016 14:50 UTC

Kamali, Mohammad Hashim. Ethical Limits on Freedom of Expression with Special Reference to Islam. Cile Journal Qatar. 2014. https:// www.cilecenter.org/en/recommended-readings/ethical-limits-onfreedom-of-expression-with-special-reference-to-islam/

Munajat, Machrus, "Pengaturan Tindak Pidana dalam Islam Berdasarkan Teori Maqasid Al-Syari'ah", dalam Jurnal Asy-Syir'ah, Volume 45, Nomor I, 2011.

Perbawati, Candra. "Penegakan Hak Asasi Manusia di Era Globalisasi dalam Perspektif Hukum Islam" dalam al-'Adalah Volume. 12, Nomor 4, Desember 2015.

Umam, Fawaizul, "Memaknai Keberagaman: the Other dalam Kontruksi Sosial Elit Kelompok-Kelompok Kegamaan di Kota Mataram”, dalam Jurnal Theologia, Volume 27, Nomor 2, Desember 2016.

Otto Yudianto, "Eksistensi Pidana Penjara Dalam Perspektif Hukum Islam Dan Hukum Adat (Kajian Pembaharuan Hukum Pidana)", dalam Jurnal Ilmu Hukum, Volume 8, Nomor 13, Februari 2012.

\section{Daftar Buku}

Audah, 'Abdul Qadir. 2011. al-Tasyri' al-Jina'i al-Islami. Jilid I. Bairut-Libanon: Darul Kutub al-Islamiyyah.

Audah, 'Abdul Qadir. Tanpa Tahun. al-Tasyri' al-Jina'i muqaranan bi alQanununi al-Wad'i. Bairut: Daru al-Kutub al-'Arobi.

Bakar, Ibnu Zayd Abdullah. 1415. Al-hudud wa al-Ta'zirat 'Inda Ibnu al-Qayyim, Dirasatun wa Muwazanatun. Riyadl: Darul 'atiyyah.

Brown, Alexader. 2015. Hate Speech Law, a Philosopical Examination. New York: Routledge

Gelber, Katharine. 2002. Speaking Back, Free Speak versus Hate Speech Debate. Amsterdam: John Benjamins Publishing Company.

Gerstenfeld, Phyllis B. 2004. Hate Crime: Causes, Control and Controversies. London UK: Sage Publications.

Hamzah, Andi. 2015. Delik-Delik Tertentu (Speciale Delicten) di dalam KUHP. Jakarta: Sinar Grafika.

Irfan, M. Nurul. Hukum Pidana Islam. Jakarta: Hamazah.

Jalaludin, Imam. 2010. Tafsir Jalalain. Bandung: Sinar Baru Algensindo.

Kasir, Isma'il Ibnu. 2000. Tafsir al-Qur'an al-'Adim. Jilid 13. Yaman: Mu'assasah Qurtubah. Hlm. 154.

Leech, N.G. 1989. Principle of Pragmatics, London: Longman.

Mahfudz, Muhammad. 2012. Diddu al-Karahiyah min Ajli Takfifi Khitabi alkarahiyah fi al-Al'alami Al'arabi. Libanon: Majma' al -Imamaini alHusnaini.

Rokhmad, Abu. 2002. Ushul Fiqh Metodologi Ijtihad Hukum Islam. Semarang: CV. Varos Mitra Utama. 
Habib, Sa'di Abu. 1985. Dirasah fì al-Minhaj al-Islam al-Siyasi. Beirut: Mu' assasat al-Rișalah.

Sihombing, Uli Parulian Dkk. 2012. Menyebarkan Kebencian Atas Dasar Agama Adalah Kejahatan, Kertas Kerja Untuk Advokasi Kebebasan Beragama Di Indonesia. Jakarta: ILRC (Indonesia Legar Resources Center).

Simanjuntak, CC Maruli. Tanpa Tahun. Atas Nama Kebencian, Kajian KasusKasus Kejahatan Berbasis Kebencian di Indonesia. Jakarta: Yayasan Bantuan Hukum Indonesia.

Weber, Anna. 1999. Hand Book of Hate Speech. France: Council of Europe Publishing.

Wolfson, Nicholas. 1997. Hate Speech, Sex Speech, Free Speech. London: Greenwood Publishing Group.

Yahya, Abi Zakariya bin Syaraf an Nawawi. 1987. Riyadu al-Shalihin. Mesir: Daaru al-Royyan Litturast.

Zahroh, Walid Husni. 2014. Inni Ukrihuka, Khitabu al-Karahiyah wa alTaifiyyah fi I'lami al-Rabi'il al-Arabi. Yordania: Center for Defending Freedom of Journalist.

Ziyad, Ibrahim Toha. 2011. Nitaq al_Masuliyyah al-Jazaiyyah 'an Jara'imi alDammi wa al-Qadhi wa al-Tahqiri. Turky: Middle East University.

Zuhaili, Wahbah. 1985. Al- Fiqhu Al-Islami wa Adillatuhu. Damaskus: Daru alFikr.

Zuhaili, Wahbah. Ushulu al-Fiqhi. Jilid II. Damaskus: Daru al-fikr.

\section{Lain-Lain}

Ahmad, Garib. Jaraim al-Ihanah wa al-Qadaf wa al-Sub. Mesir: al-Niyabah alIdariyah.

Buku Saku Penanganan Ujaran Kebencian (hate speech), Tth, Komisi Nasional Hak Asasi Manusia.

Kitab Undang-Undang Hukum Pidana (KUHP)

UU No. 39 Tahun 1999 tentang HAM

UU No 40 Tahun 2008 tentang Penghapusan Diskriminasi Ras dan Etnis

UU No 11 Tahun 2008 tentang Informasi dan Transaksi Elektronika

UU No 7 Tahun 2012 tentang Penanganan Konflik Sosial

Peraturan Kapolri nomor SE/06/X/2015 